\title{
CANADIAN JOURNAL OF
}

\section{Disability Studies}

Published by the Canadian Disability Studies Association · Association Canadienne des Études sur I'Incapacité

\section{Canadian Journal of Disability Studies}

Published by the Canadian Disability Studies Association Association Canadienne des Études sur le Handicap

Hosted by The University of Waterloo

$\underline{\text { www.cjds.uwaterloo.ca }}$

cjdseditor@uwaterloo.ca

This document has been made accessible and PDF/UA compliant by Accessibil-IT Inc. For more information go to 


\title{
Bonnie Burstow (Ed.) (2016). Psychiatry Interrogated: An Institutional Ethnography Anthology. Basingstoke: Palgrave Macmillan. \\ ISBN 978-3-319-41173-6.
}

\author{
Reviewed by Matthew S. Johnston \\ Carleton University \\ matthew.johnston3@carleton.ca
}

Say what you will about "critical/anti-psychiatry" — or what the late Thomas Szasz (2010) clarified to mean "anti coercion"- this volume interrogates the psychiatric apparatus with an evidentiary scorn and authority that demands accountability and an apologetic response. This scathing indictment of psy-professionals who mobilized psychiatric knowledge and practices to degrade, torture, and gravely harm others will serve to (1) educate skeptics; (2) bolster activism and solidarity in the Mad Movement; (3) vindicate survivors of psychiatric violence and coercion who often experience their suffering and struggle in a void of isolation; (4) provide hope to the many disgruntled professionals working in the mental health field who question their assumed role in helping people; and (5) draw ferocious critique from countless agents who wholeheartedly defend the idea that psychiatry can/will/does help/treat/cure sickly people, whether with complete, partial, or entirely without our consent.

It is clear from the first chapter that Bonnie Burstow is not shy about her abolitionist politics, nor does she offer even the remotest acknowledgment of its many tensions. Yet readers will experience this anthology as liberating on a far deeper level than the capacities of ideology afford, because the editor does not force her agenda on any of the contributors, nor on those reading their chapters. From the outset, she encourages us to draw our own conclusions, andcontra the will of some who practice psychiatry or work in the mental health system - to think for ourselves. As a survivor of psychosis, which I would personally describe as a visual, auditory, and spiritual hell, and less, as Burstow defines it: "ways of being, thinking, or acting 
that others do not understand" (13)_- I acknowledge my own concerns about drawing on an antipsychiatry ideology that can be very misleading when expressed casually and without attention to the problematic ways in which these ideas were managed historically. For example, Szasz, perhaps the most notorious pioneer of the psychiatric abolitionist movement, is cited quite generously throughout the book, without reference to how he also mobilized these libertarian views to have people killed by the state (Szasz, 2004), or deinstitutionalized without adequate community care and support (Schaler, 2004; Stroman, 2003; Novella, 2008). Some of the book's authors, more than others, see possibilities for psychiatry's continued existence, albeit much less coercively, after it has sufficiently responded to the indignities and crimes against humanity that are documented in this text, and many others (see, for example, Breggin, 2008; Burstow, 2015; Holmes et al., 2012; Johnston \& Kilty, 2014, 2016; Mason, 2006; Meyer et al., 2005). Still, I encourage readers to take a deep breath if their impulses tempt them to write off the authors who have simply had enough of psychiatry. As we come to learn in the chapters, most authors and activists who make a case for psychiatry's (eventual) extinction or grandiose reform do so because they (or their loved ones) have been irreversibly damaged because of psychiatry, not because of the circumstances that prompted their encounter.

The collection's most important objective is to "shed a critical light on psychiatry" (2), and indeed, every chapter fulfills that aim. Written primarily by graduate students, psychiatric survivors, activists, former "caregivers" and people employed by the mental health system, readers will be refreshed to learn that the collection as a whole does not smell of the ivory tower. That confusing, irritating odor (or approach to writing) has been replaced with a lucid aroma, one which translates into accessible words and stories that, in painstaking detail, tell us about how psychiatric survivors and even agents of the asylum continue to face victimization, suppression, 
stigma, (re)traumatization, and injustice once they become entrapped within the psychiatric vortex. To trust and listen to the voices of those who encounter such harm and live unbearably inside institutions of social control has never been more urgent in societies that, on an everyday, widespread, systematic level, emphasize psychiatric survivors as passive recipients of psychiatric care who are unable to comprehend their own "sickness" or behaviour better than psychiatric experts (Cohen, 2008; Kirmayer et al. 2015; LeFrançois et al., 2013; Liegghio, 2013; Noorani, 2013). Burstow ambitiously claims that every chapter, in some way, "breaks new ground" (15), and in fact, a few of them will "shock" (pun intended) and terrify readers with new insights into how psychiatry sometimes attacks and disturbs people in ways that are more obscene and unthinkable than the afflictions (or perceived afflictions) that precede their encounter.

In the afterword, Burstow quotes one reviewer who, to paraphrase, condemned the entire book as an abomination to institutional ethnography (230). Such hostility may lead some readers to err on the side of scientific validity and question whether the book lives up to its second and more methodological purpose: "to bring the power of institutional ethnography to bear in the process" (2) of critically examining the discourses and practices embodied within the global mental system. Although the text is not the first of its kind to loosely or "open-mindedly" (230) draw on elements of IE to help formulate a critique and investigation of psychiatric regimes (See Holmes et al., 2014), some chapters (especially Chapter 2) convinced me that IE facilitated the authors' discoveries and strengthened how they articulated them. Others simply offered a tribute to Dorothy Smith before delving into what really matters; namely, what they found or experienced, rather than how they found it. The person who finds something important to say by plotting a map and following it closely is no more glorious than the one who stumbles upon torment through experience, and then uses whatever resources, intellect, and methods at their 
disposal to show and teach others. Secondly, anyone who focuses their reading on method in this way does so more ironically than productively, considering the whole point of the project is to problematize the very ways in which "scientific" disciplines use rules, regimes of truth, and "boss texts" to dominate how people perceive the world, oust professionals who no longer want to proliferate healthcare violence, and invalidate those who want to recover from its harms on their own terms. In keeping with this caution, let us take a deeper look into what some of these chapters offer us.

In Chapter 11, "By Any Other Name: An Exploration of the Academic Development of Torture and Its Links to the Military and Psychiatry," Efrat Gold tells us how Dr. John Zubek, a leading psychologist at the University of Manitoba, spent a great deal of his illustrious career torturing his students in experiments (some of whom he coerced into participating) vis-à-vis sensory deprivation, isolation, captivity, and immobilization. The chapter vividly showcases how Zubek exhausted his creative capacity to develop "techniques" that could pinpoint the breaking points of subjects in interrogation settings. These findings, alongside a number of other "researchers" doing similar "work" in the middle of the century, nourished the myriad networks of secret service and intelligence agencies who wanted techniques to extract information from unwilling subjects, or influence those who they felt needed to have a sudden change of heart. What is more disturbing than the very thought that these experiments actually took place in the bowels of a Canadian university is the fact that they were funded and rendered ethical by our institutions and research boards.

If readers are quick to dismiss this case as the evil deeds of "one bad apple" that happened long ago, then you most definitely did not read Chapter 2, "Stopping CAMH: An Activist IE Inquiry," by Bonnie Burstow and Simon Adam. Not only do we learn from this 
section how problematic psychological experimentation is still ongoing, we get a revealing glimpse of how established mental health organizations use mystic forms of bureaucracy, employ tactics of deceit, and cherry-pick convenient sayings from "boss texts" (AKA the banality of evil) to hide their actions from the public. In 2012, the Centre for Addiction and Mental Health (CAMH) in Toronto placed ads on Craigslist to recruit depressed, desperate, vulnerable, impoverished people at the end of their rope to take part in "safe" electroshock “treatments" (experimentations), in exchange for a few hundred dollars. After Burstow and her small army of activists challenged CAMH to stop what they were doing, and make changes to the research ethics boards that allowed this "research" to continue, we are left to question if the research actually came to a halt, and if meaningful reforms materialized in relation to their ethical processes and approval boards. Why? Because people doing psychiatric and psychological research not only get to decide what is moral and immoral, right and wrong, ethical and unethical (and determine if there has been a breach), but there are no current and overriding governmental laws that force them to publicly justify the purpose of their experiments, or make known whether they completed a meaningful investigation of their wrongdoings.

And since agents drawing on the powers of the psy-complex possess near impermeable authority to decide and convince others what counts as knowledge of the mind, many of us, very early in our lives, come to always/already assume that mental health professionals always use that knowledge to help people, and not to hurt them (see Burstow et al., 2014). The problems with that kind of thinking are evident in Chapter 3, "A Kind of Collective Freezing-Out: How Helping Professionals' Regulatory Bodies Create 'Incompetence' and Increase Distress,” by Chris Chapman, Joanne Azevedo, Rebecca Ballen, and Jennifer Poole. There, we are presented 
with two stories of women who lost their jobs in the nursing and care profession because their colleagues, superiors, and governing regulatory bodies were able to pathologize and reinforce (over and over) their social behaviour, struggles, and resistances as a product of grave "mental illness."

A similar narrative appears in Chapter 8, "The Caring Profession, Not So Caring?: An Analysis of Bullying and Emotional Distress in the Academy," by Jemma Tosh and Sarah Golightley, where both authors unfold their experiences with intellectual violence and attempted exile while working as a graduate student and faculty member in a social work and psychology department. The academy is not immune to psychiatric power. While the DSM is generally an open-access weapon that can be unloaded for malevolent and stigmatizing purposes by anyone remotely familiar with it, Tosh and Golightley's stories warn us that those who know it best, such as mental health professionals and university researchers, also abuse it best. Chapters 3 and 8 both show readers how anyone driven by envy, spite, racism, and queerphobia can disguise their prejudices by deferring to discourses that designate the people they have problems with as defective and inhuman - especially when they perceive their colleagues' actions as stepping outside of what is thought to be "professional" conduct. It is unclear from what was shared in both chapters the degrees to which the people belittled in their workplaces crossed professional boundaries. Some part of me felt empathy towards their accusers (who were often their superiors) in acknowledgment that their positions, especially in health professions such as nursing, dictate responsibility, loyalty, and liability to the codified standards of professional performance (i.e., posing a risk of substance use as a hospital employee places many in a precarious position). Both chapters heavily imply that hatred, revenge, and discrimination were at the forefront of the survivors' victimization, however I think more could be said about how 
mental health professionalism is so absorbed by "policy" that social acceptance, empathy, and leniency rarely applies to care workers who do not always behave in ways that are considered normative.

Chapter 4, "Spirituality Psychiatrized: A Participatory Planning Process," by Lauren J. Tenney, challenges readers to become open-minded about the spiritual dimensions that shape experiences with madness and recovery, and problematize how survivors and benefactors of such trials are usually dismissed as ill and insane. Although I believe this chapter is the best example of thinking about mental health beyond scientific terms, it also raises the most tension. Tenney focuses her argument on what Seth Farber (2013) recently called the spiritual "gift" of madness, but it is necessary to admit that alongside that reality is the "badness of madness," the demonic and ineffable energies that cause unspeakable suffering and spiritual isolation, and leave our loved ones in the dark, wondering what to do. Consider a story told by a psychiatric survivor of psychosis in one of Farber's (1993) earlier works (which Tenney cites in passing), after she escapes her psychiatrist's office:

And I found myself standing outside on the sidewalk. And I was directed to look to my left and out across a field. I did, and my eyes landed on three crosses of a church...And I knew I was supposed to go there. And I started walking across the field. My mother, I heard her calling me. I wasn’t going to look back. I just kept walking. And I felt her coming, and I turned and I saw her coming across...there was a highway and another field between me and the crosses. I turned around and my arm went up and pointed at her and my voice said, "Get away from me, Satan!"...I was not possessed, because I was conscious and I agreed with what was happening, even though it sort of puzzled me, in a way...And after I said that 
to her I climbed over the fence and I walked across the four-lane highway, and I was aware that normally I would look to the right and left to see if there were any cars coming. But I did not turn my head to the right or the left because I was aware, I could feel, that there were no cars. Obviously there weren't; I did not get run over, nobody put their breaks real fast or anything. (pp. 73-74)

We know from this story what the survivor believed was real. But what must it have felt like for a mother to watch her daughter, whom she believed was ill and unable to control herself, cross a four-lane highway without looking, uttering what could have been her final words to her, "Get away from me, Satan!" Can we assume everyone would make it across that highway? That is not to say that all involuntary psychiatric recovery methods should always be looked at as a full blessing - my own psychotropic journey escaping the fires of psychosis was an icy wasteland of numbness and, for a year, translated into a total loss of my sense of self. But those spectating at what, for some, is very real torment, are left questioning if/how they should bring us back. Since the chapter deals with spiritual understandings of madness, I think it is worth mentioning that Jesus spent a great deal of his ministries removing demons and unclean spirits from people who, today, would likely be identified as mad, deranged, dangerous, and suffering from "mental illness." Not only did their families express their gratitude for Jesus's love, pity, and healing, but also those who were restored spent the rest of their lives telling others how much God had done for them (see, for one example, Dennis et al., 2008, Luke 8: 26-39).

Not all of us have the faith and know-how to perform an exorcism, but this chapter signals an opportunity for the Mad Movement to extend its compassion to those who care about our wellbeing, even when they interrupt our resistance. I had similar feelings after reading Chapter 5, "Operation ASD: Philanthrocapitalism, Spectrumization, and the Role of the Parent," 
by Mary Jean Hande, Sharry Taylor, and Eric Zorn. Undoubtedly, the help that those labeled as autistic need is not always psychiatric assistance. Yet by understanding the challenges faced by parents of children who do not fit in well because of how our societies are structured, most of us can agree that they need some kind of help, and sometimes, a lot of it (see Simplican, 2015). The chapter did its best to claw back judgment on parents who rely on the DSM and mental health professionals to get through life, but I would acknowledge more bluntly that when parents become desperate, it is not always without reservation that they become willing to try anything if they believe it is in the best interests of their child. Still, Hande and her colleagues stress that more can be done to help parents of (dis)abled children make better decisions and promote their child's autonomy, and mention (as is the case in several other chapters), that capitalism, saneism, and a general lack of available options for parental assistance are more to blame than the families trying to navigate an uncaring societal circus that is often more concerned with asserting difference than thinking up ways to stop treating others as different.

Burstow offers a disclaimer in the finale of this legendary anthology that "it is beyond the scope of this book to articulate in any detail where solutions lie" (228). Many, however, are articulated, and others follow (dare I say) logically from the evidence that is documented. To sum up, any research done in the name and under the influence of psychiatry needs to be overseen and screened by outsiders (indefinite probation, even, is justifiable), and psychiatric rules of governance and accountability need to be rewritten in light of the fact that horrible atrocities and sickening forms of experimentation are still occurring. Moreover, researchers educating people in this field need to repent more thoroughly for their predecessors' crimes, reflect deeply on their teaching, and, with the help of colleagues outside of such influence, seriously consider the value and ethics of their research well before they carry it out. 
More attention should likewise be drawn to how psychiatric institutions create as much (if not more) healthcare violence than the "pathologies" that precede institutionalization. This is due to asylums' depriving settings, infantilizing conditions of containment, and hyper-masculine security cultures that enforce its rules and doctrines (see Holmes \& Murray, 2011; Johnston, 2014; Johnston \& Kilty, 2015). If one wishes to claim that some forms of suffering do in fact create states of dangerousness, Chapter 7, "Pathologizing Military Trauma: How Services Members, Veterans, and Those Who Care About Them Fall Prey to Institutional Capture and the DSM," by Lauren Spring, makes a better case more than any that the brain is less at fault for mental suffering than our governments and societies. Just as it might seem reasonable that refusing to send Canadians off to war to be maimed, traumatized, or forced to kill others could drastically reduce or eliminate PTDS in the military, this text calls us all to treat everyone we see with respect and love in our everyday lives, in hopes that our accumulating social and societal suffering may not lead us to the path of adoption by psychiatry. And for those who have already been scarred, who will never let their guard down, and will continue to fight the good fight, we are owed a response. Now that the light is on you, psychiatry, tell us: what do you have to say for yourself?

\section{References}

Breggin, P. (2008). Brain-disabling Treatments in Psychiatry: Drugs, Electroshock, and the Psychopharmaceutical Complex. New York: Springer.

Burstow, B., LeFrançois, B. A., \& Diamond, S. (Eds.) (2014). Psychiatry Disrupted: Theorizing Resistance and Crafting the (R)evolution. Kingston: McGill-Queen's University Press. 
Burstow, B. (2015). Psychiatry and the Business of Madness: An Ethical and Epistemological Accounting. New York: Palgrave.

Cohen, B. M. Z. (2008). Mental Health User Narratives. London: Palgrave.

Dennis, L. T. (2008). English Standard Version Study Bible. Wheaton: Crossway.

Farber, S. (1993). Madness, Heresy, and the Rumor of Angels: The Revolt Against the Mental Health System. Chicago: Open Court Publishing Company.

Farber, S. (2013). The Spiritual Gift of Madness: The Failure of Psychiatry and the Rise of the Mad Pride Movement. Rochester: Inner Traditions.

Holmes, D., \& Murray, J. (2011). Civilizing the 'Barbarian': A critical analysis of behaviour modification programmes in forensic psychiatry settings. Journal of Nursing Management, 19(3), 293-301.

Holmes, D., Rudge, T., Perron, A., \& St-Pierre, I. (Eds.) (2012). Re-thinking Violence in Healthcare Settings: A Critical Approach. Surrey: Ashgate.

Holmes, D., Jacob, J.D., \& Perron, A. (Eds.) (2014). Power and the Psychiatric Apparatus: Repression, Transformation and Assistance. Surrey: Ashgate.

Johnston, M.S., \& Kilty, J.M. (2016). "It's for their own good": Techniques of neutralization and security guard violence against psychiatric patients. Punishment \& Society, 18(2), 177-197.

Johnston, M.S., \& Kilty, J.M. (2015). You gotta kick ass a little harder than that: The subordination of feminine, masculine, and queer identities by private security in a hospital setting. Men and Masculinities, 18(1), 55-78.

Johnston, M.S., \& Kilty, J.M. (2014). Power, control and coercion: Exploring hyper- 
masculine performativity by private guards in a psychiatric ward setting. In D. Holmes, J.D. Jacob, \& A. Perron (Eds.) Power and the Psychiatric Apparatus: Repression, Transformation and Assistance (pp. 61-90). Surrey: Ashgate.

Johnston, M.S. (2014). “Telling masculine tales": Tracing my embodied experience as a psychiatric ward security guard through ethnographic narrative writing. Sociology Mind, 4(2), 161-173.

Kirmayer, L., Lemelson, R., \& Cummings, C.A. (Eds.) (2015). Re-Visioning Psychiatry: Cultural Phenomenology, Critical Neuroscience, and Global Mental Health. Cambridge: Cambridge University Press.

LeFrançois, B.A., Menzies, R., \& Reaume, G. (Eds.) (2013). Mad Matters: A Critical Reader in Canadian Mad Studies. Toronto: Canadian Scholars' Press.

Liegghio, M. (2013). A denial of being: Psychiatrization as epistemic violence. In B.A. LeFrançois, R. Menzies \& G. Reaume (Eds.), Mad Matters: A Critical Reader in Canadian Mad Studies (pp. 122-129). Toronto: Canadian Scholars' Press.

Mason, T. (Ed.) (2006). Forensic Psychiatry: Influences of Evil. Totowa: Humana Press.

Meyer, C., Borch-Jacobsen, M., Cottraux, J., Pleux, D., \& Van Rillaer, J. (Eds.) (2005). The Black Book of Psychoanalysis: To Live, Think and Feel Better Without Freud. Paris: Les Arènes.

Noorani, T. (2013). Service user involvement, authority and the 'expert by experience' in mental health. Journal of Political Power, 6(1), 48-68.

Novella, E.J. (2008). Theoretical accounts on deinstitutionalization and the reform of mental health services: A critical review. Medicine, Health Care and Philosophy, 11, 303-314. 
Schaler, J.A. (Ed.) (2004). Szasz Under Fire: The Psychiatric Abolitionist Faces his Critics. Chicago: Carus Publishing Company.

Simplican, S.C. (2015). Care, disability, and violence: Theorizing complex dependency in Eva Kittay and Judith Butlet. Hypatia, 30(1), 217-233.

Stroman, D.F. (2003). The Disability Rights Movement: From Deinstitutionalization to Self-Determination. Lanham: University Press of America.

Szasz, T. (2004). The legitimacy of the defense of insanity: A reply by Thomas Szasz. In J.A. Schaler (Ed.), Szasz Under Fire: A Psychiatric Abolitionist Faces his Critics (pp. 202-224). Chicago: Carus Publishing Company.

Szasz, T. (2010). Psychiatry, anti-psychiatry, critical psychiatry: What do these terms mean? Philosophy, Psychiatry, \& Psychology, 17(3), 229-232. 